\title{
Impact of Various Types of Polluted Water, Rhizome Size and Water Depth on Sprouting of Common Cattail (Typha latifolia L.) Rhizomes
}

Bakhtiar Gul ( $\sim$ bakhtiargul@aup.edu.pk)

the University of agriculture Peshawar

Alma Ghayasuddin

the university of Agriculture Peshawar

Haroon Khan

the university of Agriculture Peshawar Pakistan

Imtiaz Khan

The University of Agriculture Peshawar

Muhammad Ishfaq Khan

the university of agriculture Peshawar Pakistan

\section{Research Article}

Keywords: water pollution, common cattail, Typha latifolia L. rhizome, rhizome fragments, rhizome sprouting, aquatic weeds, ecological weed control

Posted Date: December 14th, 2021

DOl: https://doi.org/10.21203/rs.3.rs-960734/v1

License: (c) (1) This work is licensed under a Creative Commons Attribution 4.0 International License. Read Full License 


\section{Abstract}

Three different studies were carried out in the Department of Weed Science, The University of Agriculture Peshawar, in January 2016 to examine the impacts of polluted water from various sources, water depths and rhizome size on the resprouting ability and establishment of common cattail rhizomes fragments after mechanical control. These experiments were arranged in Completely Randomized Design (CRD), replicated thrice. The selected experimental units were pots 20 inches wide and 12 inches deep. Typha latifolia L. rhizomes were placed in each pots and covered with a little silt to avoid it's direct contact and desiccation from sunlight. The impacts of water quality on T. latifolia rhizomes sprouting were significant. Lowest ratio of sprouted and un-sprouted buds (50.00\% each), 1 st sprout length (37.33 and $40 \mathrm{~cm}$ ), average sprout length (17.47 and $16.96 \mathrm{~cm}$ ), average biomass (9.99 and $10.27 \mathrm{~g}$ ) and growth rate $(0.172$ and $0.196 \mathrm{~g} /$ day $)$ were noted for saline water and industrial acidic effluents, respectively. However, highest rhizome sprouting was recorded for tap water applied as check followed by industrial effluent alkaline. The data regarding the impact of water depth on T. latifolia rhizome sprouting showed that sprouting $(44.44 \%), 1 \mathrm{st}$ sprout length $(43.33 \mathrm{~cm})$, average sprout length $(20.99 \mathrm{~cm})$, average sprout biomass $(7.84 \mathrm{~g})$, average diameter of the newly formed rhizome $(0.24 \mathrm{~cm})$ and growth rate $(0.4233$ $\mathrm{g} /$ day) were recorded for rhizomes placed at zero level water depth, while maximum buds sprouted at 4 inches water depth. Similarly, impact of rhizome size on resprouting revealed that minimum bud sprouting $(44.44 \%), 1$ st sprout length $(44.86 \mathrm{~cm})$, average sprout length $(0.93 \mathrm{~cm})$ and biomass of newly formed rhizome $(4.97 \mathrm{~g})$ and minimum days to emergence (9) were noted for smaller rhizome length (2 buds) compared to longer rhizomes with 10 buds. Therefore, on the basis of our findings, saline and industrial effluent acidic, no standing water (zero water surface level) and shorter rhizome size resulted in least bud sprouting and minimized the chance of further infestation in an eco-friendly and ecological way without the use of herbicides. Whereas alkaline industrial effluents, standing water up to 4 inches and longer rhizome fragments enhanced sprouting and re-establishment of the T. latifolia and these strategies can be utilized where the aim is to grow and establish a good stand of $T$. latifolia for passive treatment and phytoremediation of industrial effluents, before draining the polluted water into fresh water bodies like rivers and streams.

\section{Introduction}

Water is indispensable for life on the planet earth. It is a non-renewable and finite commodity and has a direct role on all life forms and aspects of life particularly the primary producers and plants (Ahmed et al. 2007). Since agriculture is the backbone of our economy (Azam, and Shafique 2017) and it is almost impossible to think of agriculture without water and where the importance of water becomes many-fold for us. Agriculture sector contributes $24 \%$ to the Gross Domestic Product (GDP) of our country. We have the world most extensive channel irrigation system and dams. The rapidly increasing population demands more water for farming as well as for agriculture based industries to process the raw agricultural products in to finishing products. The present per capita water availability in the country $\left(1000 \mathrm{~m}^{3}\right.$ ) indicates water scarcity in Pakistan (Khalid and Begum 2020). So, the factors affecting the 
water and its quality are highly significant to consider for avoiding water scarcity and plan for the future of water. One factor that deteriorates the water bodies are aquatic weeds. Besides destroying water quality they hinder the intended use of water and limit its use for irrigation, drinking, fishing, surfing, boating. Presently some water bodies have invasive aquatic weeds while the rest are vulnerable to be infested soon if the water pollution and invasive aquatic weeds are left unchecked in the absence of a comprehensive management plan, as water pollution and weeds infestation are directly related to each others. Moreover invasive weeds threaten native vegetation, human health, environment and economy (Schmidt and Drake, 2011). They change ecosystem processes and alter nutrient recycling and distribution patterns ( Maguire et al., 2011; Marwat et al., 2010). They once established permanently exclude native plants (Davies and Sheley, 2011) and harm the biodiversity. Invasive weeds coupled with climate change, deforestation and pollution result in environmental degradation.

Various types of polluted water support or suppress various weeds depending upon the clarity, $\mathrm{pH}$, salinity, nutritional quality, depth, movement and temperature of water. Variation in quality is caused by sediments, nutrients run off from agricultural land and effluents from drains and industries etc. As we have no system for water purification, the waste water drains in to the fresh water bodies, deteriorating water and encourages the growth of noxious aquatic weeds, reducing biodiversity of plants and aquatic fauna. Excessive algal growth often results in water blooms, increasing BOD that harms fish and other aquatic wildlife.

Some aquatic weeds harm ecosystem through release of allelochemicals while other invade the aquatic ecosystem and push out the native plants necessary for the ecosystem health and balance (Gopal and Goel 1993). Among them $T$. latifolia commonly known as cattail is the 2 nd most problematic aquatic weed after water Eichhornia crassipes in Pakistan. It is an emergent perennial aquatic weed having an extensive rhizome system that spreads by several meters each season. It grows often in dense monospecific thickest causing habitat destruction and loss to biodiversity.

T. latifolia grow in shallow and slow moving or standing water from 1-2 feet or more if water is clear (Rook et al. 2004). On the other hand it can grow on wet or seasonal flooded soils and can tolerate dry condition for months once established. It prefers alkaline waters but can also grow in slightly acidic or saline waters (Vymazal, (2013). It is utilized for the phytoremediation of drainage waters (Farid et al., 2014). It has the ability to bio-acummulate nutrients including heavy metals from waste water and can reduce the amount of toxic nutrients, total dissolved solids (TDS), nitrates, sulphates, carbonates and complex biological molecules that are washed away in the aquatic ecosystem (Carranza-Álvarez et al., 2008). T. latifolia along with some other aquatic weeds may result in a better phytoremediation as each aquatic plants has different affinity for the bio-accumulation different nutrients.

The rapid industrialization, increased mining, enhanced agrochemical usage and waste water draining in to irrigation channels have increased toxic nutrient load in water, threatening agriculture production, animal husbandry and human health. The present study is carried out: To investigate the effect of various types of polluted waters, rhizome size and water depth on resprouting ability and development of 
T. latifolia. To device the most effective ecological control method for T. latifolia on basis of our findings and to recommend the use of $T$. latifolia for the phytoremediation and passive water treatment of specific water quality where it flourish well and can bio-accumulate toxic load of nutrients from water.

\section{Materials And Methods}

Three experiments were conducted in The University of Agriculture Peshawar during spring 2016 to evaluate the Impact of various types of polluted waters/ water quality, rhizome size and water depth on the resprouting ability of Typha latifolia L. rhizomes. The rhizomes were collected from ponds within Peshawar. The experiments were arranged in Completely Randomized Design (CRD) each with tree replications. The experimental units consisted of pots 20 " wide and 12 " deep. Rhizomes were cut in to pieces depending on the number of prominent buds on them according to the experimental plan. Each smaller piece had at least two prominent buds to re-sprout from. Rhizomes were placed in pots and covered with silt. Water levels were maintained upon the rhizomes according to the mentioned plan of work. The details of the various experimental trials are as under:

In the Trial 1, eight water qualities i.e. the Industrial effluents acidic, industrial effluents alkaline, Bog and marshland water, Drainage water, Stream water, Irrigation channel water, Stagnant pond water, Brackish water/ saline water and Tap water as a check were applied to the pots as various water quality treatments. In the Trial 2, five water levels i.e. surface level or at 0 level, 2", 4", 6" and 8" deep were applied to the pots. While in the Trial 3, five rhizome length i.e. rhizome with $2,4,6,8$ and 10 bud were applied to the pots.

Data was recorded on the following parameters.

\section{Number of sprouts after 3 and 5 wks}

The number of sprouts were recorded daily as well as after 3rd and 5th week and at the end of the trail.

\section{Ratio of sprouted and un-sprouted buds}

Ratio of sprouted and un-sprouted buds were calculated at the end of experiment by calculating the total number of buds on the planted rhizomes at the start of trial and the recorded sprouted buds on that particular rhizome piece.

\section{1 st Sprout length individually}

Length of the $1 \mathrm{st}$ sprout was measured at the end of the trial i.e. after 45 days in $\mathrm{cm}$. From which it can be calculated its growth rate in $\mathrm{mm}$ per day.

\section{Average sprout length $(\mathrm{cm})$}

Length of each sprout was measured in $\mathrm{cm}$, combined and average was calculated by dividing on the number of sprouts measured at the end of the trial. 


\section{Average biomass $(\mathrm{g})$ of the sprouts}

Biomass of each sprouts was measured, combined and average was calculated by dividing on the number of sprouted sampled at the end of the trial.

\section{Average length of newly formed rhizome}

The size of newly formed rhizome from each sprout was measured and average length was calculated by dividing on the number of rhizomes.

\section{Average biomass (g) of newly formed rhizome}

Average biomass of newly formed rhizome was measured by measuring the total biomass of the newly formed rhizomes and was divided on the number of rhizomes.

\section{Average diameter of the newly formed rhizome}

Diameter of newly formed rhizomes was measured and average was calculated by combining all the values and then dividing on the number of rhizomes measured.

\section{Days to emergence from soil surface}

Days to emergence from the soil surface was counted from the day of rhizome planting to the day on which the sprout appears above the soil surface.

\section{Growth rate (g/day)}

Growth rate of the plants were measured by measuring biomass of the individual plant, then by subtracting the initial biomass and divided the difference by the number of days during which the biomass has been formed.

\section{Statistical Analysis}

The data recorded individually for each parameter was statistically analyzed, using analysis of variance (ANOVA) techniques suitable for Completely Randomized Design (CRD) like the statistical software GenStat release 8.1 (GenStat, 2005) and MSTATC. Means were compared by using LSD test at 0.05 level of probability, where the F-values were significant (Steel and Torrie, 1980).

\section{Results And Discussion}

Trial. 1. Impacts of water quality on T. latifolia rhizomes resprouting

\subsection{Number of sprouts periodically after 3 and 5 weeks}

Table-1 shows statistical analysis of the data regarding T. latifolia number of sprouts as affected by different water qualities. The mean data after 3rd weeks of application of water qualities showed nonsignificant effect, however, minimum sprouting were observed for industrial effluents acidic, bog and 
marshland water, stream water, stagnant pond water and saline water as compared to irrigation channel water, tap water, industrial effluents alkaline water and drainage water. Whereas various water qualities affected $T$. latifolia rhizomes buds sprouting significantly after 5 th weeks and lowest number of sprouts (1.00) were noted for industrial effluents acidic followed by saline water (1.33), while highest resprouting (3.00) were recorded for tap water followed by irrigation channel water (2.67). Among the water quality, industrial effluents acidic and saline water suppressed sprouting in contrast of tap water and irrigation channel water. These results are supported by the findings of Gorai et al. (2006) who reported that common cattail is highly susceptible to saline environment and is negatively influenced by saline soil condition.

Table-1. Impact of water quality on T. latifolia number of sprouts after 3 and 5 weeks.

\begin{tabular}{|lll|}
\hline Treatments & \multicolumn{2}{c|}{ Number of sprouts periodically after $\mathbf{3}$ and $\mathbf{5}$ weeks } \\
\cline { 2 - 3 } & 3rd week & 5th week \\
\hline Industrial effluents acidic & 1.00 & $1.00 \mathrm{a}$ \\
\hline Industrial effluents alkaline & 1.67 & $2.00 \mathrm{~b}$ \\
\hline Bog and marshland water & 1.00 & $1.67 \mathrm{ab}$ \\
\hline Drainage water & 1.33 & $1.60 \mathrm{ab}$ \\
\hline Stream water & 1.00 & $1.67 \mathrm{ab}$ \\
\hline Irrigation channel water & 2.00 & $2.67 \mathrm{c}$ \\
\hline Stagnant pond water & 1.00 & $2.00 \mathrm{~b}$ \\
\hline Brackish saline water & 1.00 & $1.33 \mathrm{ab}$ \\
\hline Tap water as a check & 2.00 & $3.00 \mathrm{c}$ \\
\hline LSD at 5\% & & 0.943 \\
\hline
\end{tabular}

\subsection{Ratio of sprouted to un-sprouted buds}

Statistical analysis of the data on the ratio of sprouted to un-sprouted buds of cattails after treatments application showed significant differences (Table-2). Lowest ratio (50\%) was noted for industrial effluents acidic, bog and marshland water and saline water followed by drainage water (83.33\%), whereas, buds sprouting were $100 \%$ in industrial effluents alkaline, stream water, irrigation channel water and tap water. The study showed that saline and industrial water acidic suppressed T. latifolia sprouting while, tape and irrigation channel water favoured resprouting. According to Wood and Zedler, (2002) T. latifolia established well in the road side drainage ditches and side of the irrigation channels. Similarly Falcinelli et al. (2017) recorded that rhizomatous plants are more sensitive to saline water. The higher rate of salinity level of water leads to death of the rhizomatous plant.

\subsection{1 st Sprout length $(\mathrm{cm})$}


Statistical analysis of common cattail rhizome data of 1 st sprout length was significantly affected by various water qualities (Table-2). The mean data regarding $T$. latifolia rhizome 1 st sprout length revealed that minimum 1st sprout length $(37.33 \mathrm{~cm})$ was noted for saline water followed by drainage water (39.67 $\mathrm{cm})$, while maximum 1st sprout length $(61.33 \mathrm{~cm})$ was observed for tap water and is followed by irrigation channel water $(58.00 \mathrm{~cm})$. this rapid growth may be due to favorable $\mathrm{pH}$, salinity and nutritional qualities of tap and irrigation water as compared to acidic effluent and saline water, where the water quality characteristics were undesirable for T. latifolia sprouting. Our findings are supported by Sojda and Solberg (1993) who reported that salinity level in water as low as 10 ppm in active growing season can suppress the growth and development of the sprouts.

\subsection{Average sprout length}

The data pertaining to the $T$. latifolia rhizomes average sprout length $(\mathrm{cm})$ at the end was significantly affected by water quality application (Table-2). Lowest average rhizome length $(16.96 \mathrm{~cm})$ was observed for industrial effluents acidic followed by saline water $(17.47 \mathrm{~cm})$, while highest were recorded for stagnant pond water $(24.77 \mathrm{~cm})$. the growth retardation in saline and acidic water might be attributed to their inappropriate nutrient availability in the concerned quality waters. These results are in line with those achieved by Mauchamp and Mesleard (2001) who reported that saline and acidic water suppresses shoot length and further infestation, as well as decreased below growth biomass ratios in cattails.

Table-2. Impact of water quality on T. latifolia ratio of sprouted vs un-sprouted buds, 1 st sprout and average sprout length. 


\begin{tabular}{|c|c|c|c|}
\hline Treatments & $\begin{array}{l}\text { Ratio of sprouted } \\
\text { vs un-sprouted } \\
\text { buds }\end{array}$ & $\begin{array}{l}\text { 1st Sprout length } \\
(\mathrm{cm})\end{array}$ & $\begin{array}{l}\text { Average sprout length } \\
\text { (cm) }\end{array}$ \\
\hline Industrial effluents acidic & $50.00 \mathrm{c}$ & $40.00 \mathrm{c}$ & $16.96 \mathrm{c}$ \\
\hline $\begin{array}{l}\text { Industrial effluents } \\
\text { alkaline }\end{array}$ & $100.00 \mathrm{a}$ & $53.00 \mathrm{f}$ & $21.34 b$ \\
\hline $\begin{array}{l}\text { Bog and marshland } \\
\text { water }\end{array}$ & $50.00 \mathrm{c}$ & $47.00 \mathrm{e}$ & 19.97 bc \\
\hline Drainage water & $83.33 \mathrm{~b}$ & $39.67 \mathrm{~b}$ & $19.26 \mathrm{bc}$ \\
\hline Stream water & $100.00 \mathrm{a}$ & $44.67 \mathrm{~d}$ & $23.56 \mathrm{ab}$ \\
\hline Irrigation channel water & $100.00 \mathrm{a}$ & $58.00 \mathrm{~h}$ & $23.66 \mathrm{ab}$ \\
\hline Stagnant pond water & $83.44 b$ & $57.00 \mathrm{~g}$ & $24.77 a b$ \\
\hline Brackish saline water & $50.00 \mathrm{c}$ & $37.33 \mathrm{a}$ & $17.47 \mathrm{c}$ \\
\hline Tap water as a check & $100.00 \mathrm{a}$ & $61.33 i$ & $26.14 \mathrm{a}$ \\
\hline LSD at $5 \%$ & 18.431 & 5.3741 & 4.3373 \\
\hline
\end{tabular}

\subsection{Average biomass $(\mathrm{g})$ of the sprouts}

Data of T. latifolia average biomass $(\mathrm{g})$ of the sprouts were significantly affected by the application of various water qualities as illustrated in the Table-3. The mean data indicated that lowest sprout biomass $(9.99 \mathrm{~g})$ was noted for saline water followed by industrial effluents acidic $(10.27 \mathrm{~g})$, whereas, the highest $(13.93 \mathrm{~g})$ biomass was seen in control (tap water), followed by stream water $(12.40 \mathrm{~g})$. The reduced biomass effluents is supported by Nagajyoti et al.(2009) who stated that the decline in growth is coupled with increase concentration of effluent.

\subsection{Average length of newly formed rhizome}

The Table-3 shows that the data about common cattail length of newly formed rhizome is significantly affected by the application of various water qualities. Differences among the treatment means of $T$. latifolia average length illustrated that minimum average length $(0.73 \mathrm{~cm})$ were recorded for saline water and is followed by industrial effluents acidic $(0.97 \mathrm{~cm})$, whereas maximum average length of newly formed rhizome after treatments implications $(1.46 \mathrm{~cm})$ was observed for tap water, followed by stagnant pond water $(1.33 \mathrm{~cm})$. So, saline and acidic water mostly suppressed rhizome growth. Therefore, the $T$. latifolia distribution and rhizome average length is mostly dependable on the water quality (Romero and Onaindia 1995).

\subsection{Average biomass (g) of newly formed rhizome}


The statistical analysis of the data of T. latifolia average biomass ( $\mathrm{g}$ ) of newly formed rhizome as influenced by adding water qualities (Table-3). Minimum biomass $(2.00 \mathrm{~g})$ of the newly formed average rhizome was noticed for industrial effluents acidic followed by saline water treatment $(2.07 \mathrm{~g})$, while, maximum ( $3.27 \mathrm{~g}$ ) average biomass of newly formed rhizome was observed for tap water and industrial effluents alkaline $(3.17 \mathrm{~g})$. Tap water and alkaline water promoted growth and enhanced rhizome sprouting. The reports of Fernald and Kinsey (1943) also indicated that T. latifolia is not salt tolerant as compare to some others species Cattail family just like $T$. angustifolia which grows well in saline water conditions.

Table-3. Impact of water quality on the T. latifolia sprouts average biomass, average length of and average biomass of newly formed rhizome.

\begin{tabular}{|llll|}
\hline Treatments & $\begin{array}{l}\text { Average biomass } \\
\text { of sprouts } \mathbf{( g )}\end{array}$ & $\begin{array}{l}\text { Average length }(\mathbf{c m}) \text { of } \\
\text { newly formed rhizome }\end{array}$ & $\begin{array}{l}\text { Average biomass (g) of } \\
\text { newly formed rhizome }\end{array}$ \\
\hline $\begin{array}{l}\text { Industrial } \\
\text { effluents acidic }\end{array}$ & $10.27 \mathrm{a}$ & $0.97 \mathrm{c}$ & $2.00 \mathrm{~d}$ \\
\hline $\begin{array}{l}\text { Industrial } \\
\text { effluents } \\
\text { alkaline }\end{array}$ & $10.86 \mathrm{ab}$ & $1.28 \mathrm{ab}$ & $3.17 \mathrm{a}$ \\
\hline $\begin{array}{l}\text { Bog and } \\
\text { marshland }\end{array}$ & $11.37 \mathrm{~b}$ & $1.07 \mathrm{~b}$ & $2.83 \mathrm{ab}$ \\
water & $11.59 \mathrm{~b}$ & $1.03 \mathrm{~b}$ & $2.23 \mathrm{~cd}$ \\
\hline $\begin{array}{l}\text { Drainage water } \\
\text { Stream water }\end{array}$ & $12.40 \mathrm{bc}$ & $1.20 \mathrm{ab}$ & $2.33 \mathrm{~cd}$ \\
\hline $\begin{array}{l}\text { Irrigation } \\
\text { channel water }\end{array}$ & $11.81 \mathrm{bc}$ & $1.22 \mathrm{ab}$ & $2.87 \mathrm{ab}$ \\
\hline $\begin{array}{l}\text { Stagnant pond } \\
\text { water }\end{array}$ & $11.43 \mathrm{~b}$ & $1.33 \mathrm{ab}$ & $2.53 \mathrm{c}$ \\
\hline $\begin{array}{l}\text { Brackish saline } \\
\text { water }\end{array}$ & $9.99 \mathrm{a}$ & $0.73 \mathrm{~d}$ & $2.07 \mathrm{~d}$ \\
\hline $\begin{array}{l}\text { Tap water as a } \\
\text { check }\end{array}$ & $13.93 \mathrm{c}$ & $1.46 \mathrm{a}$ & $3.27 \mathrm{a}$ \\
\hline \begin{tabular}{l} 
LSD at $5 \%$ \\
\hline
\end{tabular} & 2.0028 & 0.4063 & 0.4228 \\
\hline
\end{tabular}

\subsection{Average diameter of the newly formed rhizome}

Table-4 describes the data of common cattail average diameter of the newly formed rhizome after treatments application. The applied water quality had significant impacts on $T$. latifolia average diameter of the newly formed rhizome. Minimum average rhizome diameter $(0.36 \mathrm{~cm})$ was observed for saline water followed by industrial effluents acidic $(0.37 \mathrm{~cm})$ while, maximum average diameter of newly 
formed rhizome $(0.53 \mathrm{~cm})$ was noted for tap water followed by $(0.46 \mathrm{~cm})$ industrial effluents alkaline, bog and marshland water, irrigation channel water and stagnant pond water. These results showed that saline and acidic waters effectively suppressed common cattail rhizome growth. These results are in line with the results of Mauchamp and Mesleard (2001) who reported that saline and acidic water suppresses decreased below ground growth of cattails and disturbed biomass ratios in cattails.

\subsection{Days to emergence from soil surface}

The impacts of water quality on T. latifolia rhizomes sprouts emergence was significant (Table-4). The analysis of means data indicated that maximum days to emergence (11.33) were taken by rhizomes in saline water, followed by those of industrial effluents acidic and stagnant pond water (10.67 each). However, minimum days to emergence were taken by tap water ( 9.17 days) followed by where industrial effluents alkaline and stream water (9.33 days each). From the results it is indicated that tap water and alkaline water was observed to minimize the days to emergence from soil surface level as compare to saline and acidic water.

\subsection{Growth rate (g/day)}

The statistical analysis of the data showed that the application different water qualities on the growth rate of common cattail had a significant effect (Table-4). The means data indicated that the lowest rhizome growth rate $(0.172 \mathrm{~g} /$ day $)$ was observed in saline water followed by industrial effluents acidic $(0.196 \mathrm{~g} /$ day). Whereas, maximum rhizomes sprouting growth rate $(0.340)$ was recorded for tap water followed by irrigation channel water (0.333). These results showed that saline and acidic water reduced the growth and development of the common cattail rhizome sprouting. Kobe et al. (2010) reported that aquatic plant growth rate depends on the limiting resources and the growth rate is directed belowground when the water and nutrients are limited or the conditions are stressful. When basic nutrient availability increased shoot growth rate as well as below the ground biomass is equally benefited. In contrast of halophytic biotypes as reported that biotypes of $T$. latifolia has the ability of growing well at salinity levels of $2.4 \%$ with a survival rate of $94 \%$ (Jesus et al. 2014). Its survival rate was $56 \%$ if treated with $2400 \mathrm{mg}$ $\mathrm{L}^{-1}$ of $\mathrm{NaCl}$ when growing in a greenhouse (Koropchak and Vitt 2013). Yet, T. latifolia can unlike T. glauca grow in acidic soil (Hotchkiss and Dozier 1949).

Table-4. Impact of water quality on T. Iatifolia average diameter $(\mathrm{cm})$ of the newly formed rhizome, days to emergence from soil surface and growth rate. 


\begin{tabular}{|c|c|c|c|}
\hline Treatments & $\begin{array}{l}\text { Average diameter of newly formed } \\
\text { rhizome }\end{array}$ & $\begin{array}{l}\text { Days to } \\
\text { emergence }\end{array}$ & $\begin{array}{l}\text { Growth rate } \\
\text { (g/day) }\end{array}$ \\
\hline $\begin{array}{l}\text { Industrial effluents } \\
\text { acidic }\end{array}$ & $0.37 \mathrm{ab}$ & $10.67 \mathrm{c}$ & $0.196 \mathrm{a}$ \\
\hline $\begin{array}{l}\text { Industrial effluents } \\
\text { alkaline }\end{array}$ & $0.46 c$ & $9.33 \mathrm{ab}$ & $0.314 c$ \\
\hline $\begin{array}{l}\text { Bog and marshland } \\
\text { water }\end{array}$ & $0.46 \mathrm{c}$ & $9.67 \mathrm{~b}$ & $0.281 \mathrm{bc}$ \\
\hline Drainage water & $0.42 \mathrm{bc}$ & $10.33 \mathrm{bc}$ & $0.254 \mathrm{~b}$ \\
\hline Stream water & $0.43 \mathrm{~b}$ & $9.33 \mathrm{ab}$ & $0.226 \mathrm{~b}$ \\
\hline $\begin{array}{l}\text { Irrigation channel } \\
\text { water }\end{array}$ & $0.46 \mathrm{c}$ & $10.33 \mathrm{bc}$ & $0.333 \mathrm{~cd}$ \\
\hline Stagnant pond water & $0.46 \mathrm{c}$ & $10.67 \mathrm{c}$ & $0.300 \mathrm{c}$ \\
\hline Brackish saline water & $0.36 \mathrm{a}$ & $11.33 \mathrm{~cd}$ & $0.172 \mathrm{a}$ \\
\hline Tap water as a check & $0.53 d$ & $9.17 \mathrm{a}$ & $0.340 \mathrm{~d}$ \\
\hline LSD at $5 \%$ & 0.0396 & 1.3102 & 0.0665 \\
\hline
\end{tabular}

Trail -2: Impact of water depths on T. latifolia rhizome buds resprouting

\subsection{Number of sprouts periodically after 3 and 5 weeks}

Rhizome sprouting of common cattail is significantly affected by their position at various water depths as shown in the Table-5. After 3rd week the impacts water depths indicated that lowest number of sprouts (1.33) were observed for zero level water, followed by 8 inch depth (1.67). However, highest number of rhizomes sprouting (2.00) observed for rhizome kept at 2, 4 and 6 inches deep in water. Similarly after 5 th week of water depth application minimum $T$. latifolia rhizomes buds sprouted (2.67) zero water level followed by 8 inch water depth (3.33 sprouts). Whereas, maximum $T$. latifolia rhizome buds (4.67 sprouts) were noticed for 4 inches water depth. The less sprouting at high water depth may be attributed to less oxygen availability or light penetration. Similar finding are reported by (Zhang et al. 2015) the periodically regrowth and rhizome sprouting by water depths is the key factor distressing the growth and development of aquatic plants. White and Ganf, (1998) also recorded that water depths have significant impacts on the aquatic emerged plant rhizome sprouting. For the optimum sprouting and development $T$. latifolia rhizome buds require a maximum of $5 \mathrm{~cm}$ water depth (Haslam, 1972). According to the finding of Squires and Van der Valk (1992) water depths had significant effects on the regrowth, distribution and rhizome buds resprouting of emergent macrophytes in wetlands.

\subsection{Ratio of sprouted and un-sprouted buds}


Table- 5 shows the impacts of water depths on the common cattail rhizomes buds sprouted and unsprouted ratio. The water depth had significantly affected $T$. latifolia rhizomes sprouting and the ratio of sprouted vs un-sprouted buds were $44.44 \%$ at 0 water level, followed by 8 inches water depth (49.33\%), whereas, highest ratio $(75.11 \%)$ was observed for 4 inches depth and followed by 2 inches depth (66.67\%). The zero level rhizome placements had low sprouting, while by increasing the water depth upto 6 inches promoted the rhizome growth. At more than 6 inches depth the rhizome decayed and had low bud sprouting which might be attributed to lack of $\mathrm{O}_{2}$ or due variation in light penetration with depth. These investigation or in line with the work of Vretare and Weisner, (2000) who reported that buds resprouting was affected by retarding of photosynthesis by increasing water depths. According to Kim et al. (2013) alteration in water depths can disrupt and enhance the resprouting. The maximum water depths mostly changed the micro environment for plant due to lack of $\mathrm{O}_{2}$ from nontoxic to toxic (Ponnamperuma 1972).

\subsection{1st sprout length $(\mathrm{cm})$}

Common cattail 1st sprout length was significantly influenced by various water depths (Table-5). Minimum $(43.33 \mathrm{~cm})$ sprout length were recorded for rhizome placed at zero water level followed by 8 inches water depth (49.33), while maximum 1st sprout length (59.00) was observed for 4 inches followed by 6 inches (57.10). Early sprouted rhizome buds markedly found with high length of the sprouts. Similar findings were obtained by Waters and Shay (1991) by reporting that the sprouting of T. latifolia from rhizomes is mostly late in the deep water, consequently, length of the first sprout of emergent aquatic plant is mostly low due to late growth. Our results are in line with the results of Mauchamp et al. (2001) who also reported that young $P$. australis plants require shallow water levels, without long lasting submergence to grow and survive

Table-5. Impact of water depths on T. latifolia rhizomes buds sprouting after 3 and 5 weeks, rhizomes sprouted and un-sprouted buds ratio and 1 st sprout length. 


\begin{tabular}{|lllll|}
\hline Treatments & \multicolumn{2}{l}{$\begin{array}{l}\text { Number of sprouts } \\
\text { periodically }\end{array}$} & $\begin{array}{l}\text { Ratio of sprouted and un-sprouted } \\
\text { buds }\end{array}$ & $\begin{array}{l}\text { 1st Sprout length } \\
\text { (cm) }\end{array}$ \\
\cline { 2 - 4 } 3nd week & 5th week & & $43.33 \mathrm{a}$ \\
\hline Zero level & $1.33 \mathrm{a}$ & $2.67 \mathrm{a}$ & $44.44 \mathrm{a}$ & $54.33 \mathrm{c}$ \\
\hline $\begin{array}{l}2 \text { inches } \\
\text { deep }\end{array}$ & $2.00 \mathrm{~b}$ & $3.67 \mathrm{~b}$ & $66.67 \mathrm{~d}$ & $59.00 \mathrm{e}$ \\
\hline $\begin{array}{l}4 \text { inches } \\
\text { deep }\end{array}$ & $2.00 \mathrm{~b}$ & $4.67 \mathrm{c}$ & $75.11 \mathrm{e}$ & $57.10 \mathrm{~d}$ \\
\hline $\begin{array}{l}6 \text { inches } \\
\text { deep }\end{array}$ & $2.00 \mathrm{~b}$ & $3.67 \mathrm{~b}$ & $61.11 \mathrm{c}$ & $49.33 \mathrm{~b}$ \\
\hline $\begin{array}{l}8 \text { inches } \\
\text { deep }\end{array}$ & $1.67 \mathrm{ab}$ & $3.33 \mathrm{ab}$ & $50.00 \mathrm{~b}$ & 6.962 \\
\hline LSD at $5 \%$ & 0.5003 & 0.854 & 5.381 & \\
\hline
\end{tabular}

\subsection{Average sprout length $(\mathrm{cm})$}

Data in the Table-6 illustrates the common cattail sprout average length was significantly affected by various water depths and the lowest average sprout length $(20.99 \mathrm{~cm})$ was noted in zero water level followed by (21.82) 8 inches water depth as compared to 4 (23.72) and 2 inches water depth (22.79), respectively. The decreased growth of $T$. latifolia in high water depth is supported by Vretare et al. (2001) who tested different water depths against $T$. latifolia rhizomes buds resprouting and reported that the increasing water depths directly influence buds sprouting, sprouts length and above water canopy coverage. Several other researchers reported that morphological responses and structural characteristics of various species of Typha to differential water depths is different but in case of $T$. latifolia deep water negatively influenced average length of the sprouts (Waters and Shay,1992).

\subsection{Average biomass $(\mathrm{g})$ of the sprouts}

Various water depths affected the sprouts average biomass significantly (Table-6). Minimum biomass $(7.84 \mathrm{~g})$ is recorded in zero water level followed by 8 inches depth (8.09), whereas, maximum sprouts biomass (9.81) was seen in 4 and then 2 inches depth (9.17). These results are in line with the findings of Cao (2007) who reported that average biomass of the T. latifolia is disrupted as the water depth increased. Similarly Sharma et al. (2008) investigated that $T$. latifolia established population produces a large rhizome biomass in shallow water as compared to deeper waters.

\subsection{Average length $(\mathrm{cm})$ of newly formed rhizome}

Average length of newly formed rhizome is significantly affected by water depths (Table-6) and least average newly formed rhizome length $(1.13 \mathrm{~cm})$ was recorded for zero water level as compared to 2 (1.30), 4 (6.27) and 6 (3.53) and 8 inches depth (1.37), respectively. Water depth had significant impacts on newly formed rhizomes length and is inversely related to water depths. These findings are similar to 
that of Vretare et al. (2001) who recorded the increasing water depth inhibited newly formed rhizome length as well as biomass.

\subsection{Average biomass (g) of newly formed rhizome}

Table-6 shows the impact of water depths on the newly formed rhizomes biomass as statistically significant. Minimum biomass of newly formed rhizome (2.49 g) was recorded for zero water level followed by 2 inches water depth (2.90) as compared to the maximum average biomass (4.15 g) for 4 and (3.64 g) 6 inches water depth. In deeper water the biomass of newly formed rhizome is probably low due low $\mathrm{O}_{2}$ or low water temperature as compared to shallower water. These results are analogous to that of Cao (2007) who reported that in deep water the emergent rhizomatous aquatic weeds are let-down from sprouting and optimum rhizomes development. Lower rhizome biomass might be due the unavailability of sunlight, $\mathrm{O}_{2}$ and adverse temperature with increase in the water depths (Zhang et al. 2013).

Table-6. Impact of water depths on T. latifolia sprouts length and average sprout biomass, average length and average biomass $(\mathrm{g})$ of newly of newly formed rhizomes.

\begin{tabular}{|c|c|c|c|c|}
\hline Treatments & $\begin{array}{l}\text { Average } \\
\text { sprout length } \\
\text { (cm) }\end{array}$ & $\begin{array}{l}\text { Average } \\
\text { biomass } \\
\text { (g) }\end{array}$ & $\begin{array}{l}\text { Average length }(\mathrm{cm}) \text { of } \\
\text { newly formed rhizome }\end{array}$ & $\begin{array}{l}\text { Average biomass }(\mathrm{g}) \text { of } \\
\text { newly formed hizome }\end{array}$ \\
\hline $\begin{array}{l}\text { Surface at } \\
0 \text { level }\end{array}$ & 20.99 a & $7.84 \mathrm{a}$ & $1.13 \mathrm{a}$ & $2.49 \mathrm{a}$ \\
\hline $\begin{array}{l}2 \text { inches } \\
\text { deep }\end{array}$ & $22.79 \mathrm{~b}$ & $9.17 \mathrm{~cd}$ & $1.30 \mathrm{~b}$ & $2.90 \mathrm{~b}$ \\
\hline $\begin{array}{l}4 \text { inches } \\
\text { deep }\end{array}$ & $23.72 \mathrm{c}$ & $9.81 \mathrm{e}$ & $6.27 \mathrm{e}$ & $4.15 \mathrm{e}$ \\
\hline $\begin{array}{l}6 \text { inches } \\
\text { deep }\end{array}$ & 22.19 bc & $8.68 \mathrm{c}$ & $3.53 \mathrm{~d}$ & $3.64 \mathrm{~d}$ \\
\hline $\begin{array}{l}8 \text { inches } \\
\text { deep }\end{array}$ & $21.82 b$ & $8.09 \mathrm{~b}$ & $1.37 \mathrm{c}$ & $3.58 \mathrm{c}$ \\
\hline LSD at $5 \%$ & 1.2172 & 0.5159 & 3.2477 & 0.852 \\
\hline
\end{tabular}

Table-7 shows that average diameter of the newly formed rhizome is significantly affected by various water depths. Minimum diameter $(0.24 \mathrm{~cm})$ was observed for zero water level followed by 8 inches deep water (0.25), while maximum diameter (0.47) was observed for 4 inches deep water, followed by 6 inches water depth (0.35). Water depth affected rhizome diameter as well as buds sprouting and average diameter of the emerged plant rhizome was probably thicker for deep water (Weisner and Strand 1996). Although, emerged aquatic plants growing in deep water produced short but thick rhizomes. Sorrell and 
Tanner (2000) reported that thick rhizomes were also noted for another aquatic Eleocharis sphacelata growing in deeper water conditions.

\subsection{Days to emergence from soil surface}

Days to emergence from soil surface were also significantly affected by the application of various water depths (Table-7). Maximum days to emergence (12.00) were taken at zero water level, followed by 8 inches water depth (11.67), whereas minimum days (10.00) were taken to emergence for 4 inches depth, followed by 2 inches (10.67). The deeper water and shallow water levels cause a delay in sprouts emergence as compared to moderate water depths. These observations are supported by Jian et al. (2001) who stated that increasing water depths had significant impacts on delaying the starting time of emergent plant rhizomes sprouting and increased the days of emergence.

\subsection{Growth rate (g/day)}

Table-7 shows significant impact of water depths on T. latifolia sprouts growth rate. Mean data showed that lowest growth rate $(0.4233 \mathrm{~g} /$ day $)$ were recorded for the zero water level followed by $(0.4833) 2$ inches water depth, whereas highest (0.6985) T. latifolia sprouts growth rate were observed in 4 inches, followed by 6 inches water depth. The reason may be light intensity and desiccation effect at zero water level as compared to deeper water. These findings are in line with the results of Coops et al. (2004) who stated the surface level as well as very deeper water levels in wetland environment probably leads to decreased growth and resprouting. In deep water the reason of low growth might be less availability of $\mathrm{O}_{2}$ rather than of nutrients and also the variation in the light intensity and water temperature (Zhang et al. 2013). According to Sharma et al. (2008) negative impact of water depths towards sprouted buds is mostly due to some morphological and physiological adaptations that enabled the plants to survive under deeper conditions. Our results are also in line with that of Vretare et al. (2001) who stated that, in shallow water, plants have an increased risk of becoming uprooted and show decreased growth and dispersal rates.

Table-7. Impacts on water depths on T. latifolia rhizome sprouted buds average diameter of the newly formed, days to emergence from soil surface and growth rate. 


\begin{tabular}{|llll|}
\hline Treatments & $\begin{array}{l}\text { Average diameter of the newly } \\
\text { formed rhizome }\end{array}$ & $\begin{array}{l}\text { Days to emergence from } \\
\text { soil surface }\end{array}$ & $\begin{array}{c}\text { Growth rate } \\
\text { (g/day) }\end{array}$ \\
\hline $\begin{array}{l}\text { Surface at } 0 \\
\text { level }\end{array}$ & $0.24 \mathrm{a}$ & $12.00 \mathrm{e}$ & $0.4233 \mathrm{a}$ \\
\hline $\begin{array}{l}2 \text { inches } \\
\text { deep }\end{array}$ & $0.32 \mathrm{~b}$ & $10.67 \mathrm{~b}$ & $0.4833 \mathrm{~b}$ \\
\hline $\begin{array}{l}4 \text { inches } \\
\text { deep }\end{array}$ & $0.47 \mathrm{~d}$ & $10.00 \mathrm{a}$ & $0.6985 \mathrm{e}$ \\
\hline $\begin{array}{l}6 \text { inches } \\
\text { deep }\end{array}$ & $0.35 \mathrm{c}$ & $11.00 \mathrm{c}$ & $0.6540 \mathrm{~d}$ \\
\hline $\begin{array}{l}8 \text { inches } \\
\text { deep }\end{array}$ & $0.25 \mathrm{ab}$ & $11.67 \mathrm{~d}$ & $0.5333 \mathrm{c}$ \\
\hline $\begin{array}{l}\text { LSD value } \\
\mathbf{5} \%)\end{array}$ & 0.1781 & 1.0504 & 0.1398 \\
\hline
\end{tabular}

Trail -3. Impact of rhizome lengths/ number of buds on T. latifolia rhizomes buds resprouting and development

\subsection{T. latifolia number of sprouts after 3 and 5 weeks}

Table-8 shows that rhizome length with different buds had a significant effect on the common cattail number of sprouted buds periodically after 3 and 5 weeks. After the 3rd week buds resprouting data indicated that lowest sprouted buds (1.67) were noted for rhizome length with 2 buds followed by 4 buds (2.33). Whereas, highest number of rhizome buds (5.00 each) were observed for rhizome length with 8 and 10 buds. Finally, after 5th week of rhizome length with different buds illustrates that minimum numbers of sprouted buds (1.67) for rhizome length with 2 buds followed by 4 buds of rhizome length (3.00). Whilst, numbers of sprouted rhizome buds were maximum for the rhizome length with 10 bud (6.33) followed by 8 buds (5.67). These findings showed that at early stage rhizome length with various buds had a significant impact on rhizome buds resprouting (Li et al., 2018).

\subsection{Ratio of sprouted and un-sprouted buds}

The impacts of rhizome length with various buds had a significant effect on the common cattail ratio of sprouted and un-sprouted rhizome buds (Table-8). The lowest ratio (44.44\%) was observed for the rhizome length with 2 buds followed by 10 buds (50.00\%). Maximum ratio of sprouted and un-sprouted buds was noted for rhizomes length with 6 buds (77.78\%), followed by 8 buds (73.81\%). These results are in line to the work of Carlsson and Callaghan (1990) who stated that the number of sprouted buds increased with the length of rhizome while on the other hand, shorter rhizome either did not sprout or sprouted very slowly.

\subsection{1st Sprout length}


The statistical analysis of the data regarding rhizome length with various buds of common cattail had a significant impact on the 1st sprout length individually (Table-8). Minimum sprout length $(44.86 \mathrm{~cm})$ was noted for rhizome length with 2 buds followed by 10 buds $(49.66 \mathrm{~cm})$, whereas, maximum 1 st sprout length $(61.12 \mathrm{~cm})$ was recorded for rhizome length with 8 buds followed by rhizome length with 6 buds (56.01). But according to Fiala (1978) there is no variability in the 1st sprouted leaf growth due to the carbohydrates stored in the rhizome. The rhizomes length had non-significant impacts on the first sprouted buds length, in contrast water level and organic matter is reported for the variability in $T$. latifolia sprouted buds length (Keddy and Constabel 1986).

Table-8 Impact of rhizome length on rhizome buds sprouting after 3 and 5 weeks, ratio of sprouted and un-sprouted buds and 1st sprout length at the end of the trial.

\begin{tabular}{|c|c|c|c|c|}
\hline \multirow{2}{*}{$\begin{array}{l}\text { Treatments } \\
\text { (Rhizome length with } \\
\text { various buds) }\end{array}$} & \multicolumn{2}{|c|}{$\begin{array}{l}\text { Number of } \\
\text { sprouts after }\end{array}$} & \multirow[t]{2}{*}{$\begin{array}{l}\text { Ratio of sprouted and un- } \\
\text { sprouted buds }\end{array}$} & \multirow[t]{2}{*}{$\begin{array}{l}\text { 1st Sprout } \\
\text { length }(\mathrm{cm}\end{array}$} \\
\hline & $\begin{array}{l}\text { 3nd } \\
\text { week }\end{array}$ & $\begin{array}{l}\text { 5th } \\
\text { week }\end{array}$ & & \\
\hline 2 buds & $1.67 \mathrm{a}$ & $1.67 \mathrm{a}$ & $44.44 \mathrm{a}$ & $44.86 \mathrm{a}$ \\
\hline 4 buds & $2.33 \mathrm{~b}$ & $3.00 \mathrm{~b}$ & $61.11 \mathrm{c}$ & $51.03 \mathrm{c}$ \\
\hline 6 buds & $3.00 \mathrm{c}$ & $4.33 \mathrm{c}$ & 77.78 e & $56.01 \mathrm{~d}$ \\
\hline 8 buds & $5.00 \mathrm{~d}$ & $5.67 \mathrm{~d}$ & $73.81 \mathrm{~d}$ & $61.12 \mathrm{e}$ \\
\hline 10 buds & $5.00 \mathrm{~d}$ & $6.33 \mathrm{e}$ & $50.00 \mathrm{~b}$ & $49.66 \mathrm{~b}$ \\
\hline LSD at $5 \%$ & 3.450 & 0.650 & 53.101 & 8.2829 \\
\hline
\end{tabular}

\subsection{Average sprout length}

Common cattail rhizomes length with various buds had a significant effect on the average sprout length $(\mathrm{cm})$ at the end of the trial (Table-9). Minimum average sprout length $(24.17 \mathrm{~cm})$ was note for rhizome length with 10, however it was statistically at par with the rhizome length containing 8 buds (24.38), while maximum average length (26.48) was seen for 2 buds followed by 4 buds $(25.24 \mathrm{~cm})$, respectively. The rhizome length with various bud had significant impacts on the common cattail sprouted rhizome average length. The increasing rhizome size generally enhanced the average length of sprouted rhizome. These findings are in conformity with the work of Carlsson and Callaghan (1990) who reported that longest rhizome had fast growth and maximum average length.

\subsection{Average biomass $(\mathrm{g})$ of the sprouts}

Table 9 shows that common cattail rhizomes length with various buds had a significant effect on the average biomass of the sprout at the end of the trial. The lowest average biomass $(8.42 \mathrm{~g})$ was recorded for rhizome length containing 10 buds, however it was statistically similar to rhizome length 2 buds (8.56 g). However, maximum average biomass $(9.59 \mathrm{~g})$ was observed for rhizome length with 4 buds and 6 
buds (9.57). According to Sharma et al. (2008) in shorter rhizomes lengths overall below-ground biomass was also significantly higher than others, which helps the plant to survive during anoxic conditions.

\subsection{Average length $(\mathrm{cm})$ of newly formed rhizome}

T. latifolia rhizomes length with various buds had a significant effect on the average length of newly formed rhizomes (Table-9). Minimum average length $(0.93 \mathrm{~cm})$ was recorded for rhizome length comprised of 2 buds followed by 4 buds $(1.17 \mathrm{~cm})$, whereas maximum average length of newly formed rhizome $(1.93 \mathrm{~cm})$ was observed for rhizome length with 10 buds followed by rhizome length with 8 and 6 buds (1.50 and $1.37 \mathrm{~cm}$, respectively). Our results are also supported by Sojda and Solberg (1993) who reported that the rhizomes elongates in early summer under un-restricted growth and in the absence of herbicides.

\subsection{Average biomass (g) of newly formed rhizome}

T. latifolia rhizomes length with various buds had a significant effect on the average biomass of newly formed rhizomes (Table-9). Minimum biomass $(4.97 \mathrm{~g}$ ) of newly formed rhizome was noticed for rhizome length with 2 buds followed by 4 buds rhizome length $(5.74 \mathrm{~g})$, while, maximum biomass of the newly formed rhizome was recorded $(7.40 \mathrm{~g})$ for where rhizome length consisting 10 buds followed by rhizome length containing 8 buds $(6.70 \mathrm{~g})$ and 6 buds $(6.30 \mathrm{~g})$, respectively. Positive correlation was seemed among the rhizome length and common cattail average biomass of the newly formed rhizome. The increasing rhizome length directly enhance biomass of the newly formed rhizomes. These results are supported by the work of Grace and Wetzel (1982) who reported that biomass allocation in Typha is greater to vegetative reproduction and rhizome formation than sexual reproduction, and flowering formation when there is less stress on the buds in terms of food supply which is more in case of lengthy rhizome fragments.

Table-9 Impact of rhizome length on T. latifolia sprouts length, sprout average biomass and average length and average biomass of newly formed rhizome at the end of the trial.

\begin{tabular}{|lllll|}
\hline $\begin{array}{l}\text { Treatments } \\
\text { (Rhizome length } \\
\text { with various } \\
\text { buds) }\end{array}$ & $\begin{array}{l}\text { Average } \\
\text { sprout length } \\
(\mathbf{c m})\end{array}$ & $\begin{array}{l}\text { Average } \\
\text { biomass } \\
(\mathbf{g})\end{array}$ & $\begin{array}{l}\text { Average length }(\mathbf{c m}) \text { of } \\
\text { newly formed rhizome }\end{array}$ & $\begin{array}{l}\text { Average biomass }(\mathbf{g}) \text { of } \\
\text { newly formed rhizome }\end{array}$ \\
\hline 2 buds & $26.48 \mathrm{~d}$ & $8.56 \mathrm{a}$ & $0.93 \mathrm{a}$ & $4.97 \mathrm{a}$ \\
\hline 4 buds & $25.24 \mathrm{bc}$ & $9.59 \mathrm{c}$ & $1.17 \mathrm{~b}$ & $5.74 \mathrm{~b}$ \\
\hline 6 buds & $24.98 \mathrm{ab}$ & $9.57 \mathrm{c}$ & $1.37 \mathrm{c}$ & $6.30 \mathrm{c}$ \\
\hline 8 buds & $24.38 \mathrm{ab}$ & $8.77 \mathrm{ab}$ & $1.50 \mathrm{c}$ & $6.70 \mathrm{~d}$ \\
\hline 10 buds & $24.17 \mathrm{a}$ & $8.42 \mathrm{a}$ & $1.93 \mathrm{~d}$ & $7.40 \mathrm{e}$ \\
\hline LSD at $5 \%$ & 0.7942 & 0.345 & 0.1694 & 1.5473 \\
\hline
\end{tabular}




\subsection{Average Diameter $(\mathrm{cm})$ of the newly formed rhizome}

Common cattails rhizomes length with various buds had a significant effect on the average diameter of newly formed rhizomes as indicated in the Table-10. Minimum $(0.29 \mathrm{~cm})$ average diameter were recorded for rhizome length consist 10 buds, followed by rhizome length contain 2 buds $(0.30 \mathrm{~cm})$, whereas maximum average diameter were $(0.52 \mathrm{~cm})$ noted 4 buds which is followed by rhizome length with 6 buds. The moderate rhizome length with $4-6$ buds proved to the optimum size for re-growth and development of rhizome; however, other than that one had a decreasing trend. These results are in line with the work of White \& Ganf (1998) who also reported convective flow plays an important role in increasing the capacity for rhizome extension by decreasing the diffusion path length especially in case of optimum size rhizome fragments during bud sprouting in green house conditions.

\subsection{Days to emergence}

Common cattails rhizomes length with various buds had a significant effect on the days to emergence from soil surface of newly formed rhizomes (Table-10). Minimum days (9.0) to emergence from soil surface were taken by 2 eyed rhizome length, followed by rhizome length with 10 eyes or buds (9.67), whereas maximum days to emergence were taken by rhizome length with 4 eyes or buds ( 10.67 days) followed by rhizome length containing 6 eyes. The rhizome length did not has a linear impacts on the time $T$. latifolia has taken to re-sprout from rhizomes. However the rhizome length with 2 eyes had significant impacts on the growth suppression of rhizome and had a reduced re-sprouting ability as well as increased time taken to emerge to the soil surface.

\subsection{Growth Rate (g/day)}

Common cattails rhizomes length with various buds had a significant effect on the cattail growth rate as indicated in the Table-10. Lowest $(0.4866 \mathrm{~g} /$ day) rhizomes growth rate was recorded for rhizome length with 10 buds, followed by rhizome length with 2 buds $(0.5 .86 \mathrm{~g} /$ day $)$, while highest growth rate $(0.5970$ $\mathrm{g} /$ day) was observed for rhizome length with 4 buds and $(0.5501 \mathrm{~g} /$ day $) 6$ buds, respectively. The 4-6 buds rhizome length was observed to grow better and enhanced the chances of buds growth rate, but, rhizome fragment smaller than that i.e. having less than 4 buds ( 2 buds fragment) was seen to reduce the chances of growth and resprouting. As stated by Sharma et al. (2008) the increase in length of the $T$. Latifolia rhizome with many buds and mass are considered for emergent plant for better establishment and also grow faster due to more stored food and growth rate.

Table-10. Impact of rhizome length on the T. latifolia average diameter of the newly formed rhizome, days to emergence and growth rate. 


\begin{tabular}{|llll|}
\hline $\begin{array}{l}\text { Treatments (Rhizome } \\
\text { length with various buds) }\end{array}$ & $\begin{array}{l}\text { Average diameter (cm) of the } \\
\text { newly formed hizome }\end{array}$ & $\begin{array}{l}\text { Days to emergence } \\
\text { from soil surface }\end{array}$ & $\begin{array}{l}\text { Growth } \\
\text { rate } \\
\text { (g/day) }\end{array}$ \\
\hline 2 buds & $0.30 \mathrm{~b}$ & $9.00 \mathrm{a}$ & $0.5386 \mathrm{~b}$ \\
\hline 4 buds & $0.52 \mathrm{e}$ & $10.67 \mathrm{e}$ & $0.5970 \mathrm{~d}$ \\
\hline 6 buds & $0.33 \mathrm{~d}$ & $10.33 \mathrm{~d}$ & $0.5501 \mathrm{~cd}$ \\
\hline 8 buds & $0.31 \mathrm{c}$ & $10.00 \mathrm{c}$ & $0.5446 \mathrm{c}$ \\
\hline 10 buds & $0.29 \mathrm{a}$ & $9.67 \mathrm{~b}$ & $0.4866 \mathrm{a}$ \\
\hline LSD at $5 \%$ & 0.2655 & 1.4092 & 0.0895 \\
\hline
\end{tabular}

\section{Conclusion}

In light of the results it is concluded that all the treatments for controlling T. latifolia were significant. Among the water qualities brackish saline water and industrial effluents acidic inhibited sprouting compared to control. Among the water depths, zero level and 8 inches depth influenced the sprouting compared to 4 and 6 inches depth, which enhanced the sprouting. Rhizome fragments with $2-4$ buds sprouted less as compared more than 4 rhizome buds.

\section{Recommendations}

On the basis of results it is recommended that the saline water and industrial effluents acidic for managing $T$. latifolia ecofriendly. Similarly by manipulating water depth cattail can be suppressed without damaging other flora and fauna. In case of mechanical weed control, the shorter fragmentations will curtail its reestablishment. Similarly $T$. latifolia can be used for the phytoremediation of waters other than saline or acidic.

\section{Declarations}

\section{Ethical Approval:}

This manuscript is not submitted any other journal. The research work original and has not been published elsewhere in any form or language (partially or in full). This work is M.Phil. thesis of my student (Alma Ghayasuddin) and has 7\% plagiarism. This paper consists of the whole research and is not split up into several parts to increase the quantity of submissions. The results are presented clearly, honestly, and without fabrication, falsification or inappropriate data manipulation. No data, text, or theories by others are presented.

\section{Consent to Participate:}


As no human or animal or their tissues are involved in the study therefore consent to Participate is "Not applicable"

\section{Consent to Publish:}

The manuscript does not contain data from any individual person, and therefore consent to Publish is “Not applicable."

\section{Author's contributions:}

\begin{tabular}{|lll|}
\hline Name of author & Contribution & Affiliation \\
\hline Blma Ghayasuddin & $\begin{array}{l}\text { Conceptualized and } \\
\text { supervised the research }\end{array}$ & $\begin{array}{l}\text { Department of Weed Science and Botany, the } \\
\text { University of Agriculture Peshawar- Pakistan }\end{array}$ \\
\hline Haroon Khan & Helped in paper write up & $\begin{array}{l}\text { Department of Weed Science and Botany, the } \\
\text { University of Agriculture Peshawar- Pakistan }\end{array}$ \\
\hline $\begin{array}{l}\text { Imtiaz Khan } \\
\text { University of Agriculture Peshawar- Pakistan }\end{array}$ \\
\hline $\begin{array}{l}\text { Muhammad } \\
\text { Ishfaq khan }\end{array}$ & $\begin{array}{l}\text { Helped in data } \\
\text { recording }\end{array}$ & $\begin{array}{l}\text { Department of Weed Science and Botany, the } \\
\text { University of Agriculture Peshawar- Pakistan }\end{array}$ \\
\hline
\end{tabular}

Competing Interests / conflict of interest: The authors have no relevant financial or non-financial interests to disclose. The authors have no conflicts of interest to declare that are relevant to the content of this article. All authors certify that they have no affiliations with or involvement in any organization or entity with any financial interest or non-financial interest in the subject matter or materials discussed in this manuscript. The authors have no financial or proprietary interests in any material discussed in this article.

Availability of data and materials: All data generated or analysed during this study are included in this published article.

Funding: Not applicable

\section{References}

1. Ahmed A, Iftikhar H, Chaudhry GM (2007) Water resources and conservation strategy of Pakistan. The Pak Develop Review 997-1009

2. Azam A, Shafique M (2017) Agriculture in Pakistan and its Impact on Economy. A Review. Inter J Adv Sci Technol 103:47-60 
3. Cao Y (2007) Study on impact factor and technique of vegetation restoration for flood beaches wetlands along Yangtze River. Dissertation Nanjing Normal Univ China

4. Carlsson BA, Callaghan TV (1990) Programmed tiller differentiation, intraclonal density regulation and nutrient dynamics in the Carex Bigelowii. Oikos 58:219-230

5. Carranza-Álvarez C, Alonso-Castro AJ, Alfaro-De La Torre MC, García-De La Cruz RF (2008) Accumulation and distribution of heavy metals in Scirpus americanus and T. latifolia from an artificial lagoon in San Luis Potosí, México. Water, air, and soil pollution 188(1):297-309

6. Coops $\mathrm{H}$, van denBrink FWB, van derVelde $\mathrm{G}$ (1996) Growth and morphological responses of 4 halophytes species in an experimental water-depth gradient. Aquat Bot 54:11-24

7. Davies KW, Sheley RL (2011) Promoting native vegetation and diversity in exotic annual grass infestations. Restor Ecol 19(2):159-165

8. Falcinelli B, Sileoni V, Marconi O, Perretti G, Quinet M, Lutts S, Benincasa P (2017) Germination under Moderate Salinity Increases Phenolic Content and Antioxidant Activity in Rapeseed (Brassica napus) Sprouts. Molecules 22(1377):2-13

9. Farid M, Irshad M, Fawad M, Ali Z, Eneji AE, Aurangzeb N, Ali B (2014) Effect of cyclic phytoremediation with different wetland plants on municipal wastewater. Int J Phytorem 16(6):572581

10. Fernald ML, Kinsey AC (1943) Edible wild plants of eastern North America. Idlewild Press CornwallON- Hudson, N.Y. http://hdl.handle.net/2027/uc1.b4313378 Accessed on 30 May 2016

11. Fiala K (1978) Underground organs of $T$. angustifolia and T. latifolia, their growth, propagation and production. Acta Scientiarum Naturalium Academiae Scientiarum Bohemoslovacae Brno 12(8):1-43

12. Gopal B, Goel U (1993) Competition and allelopathy in aquatic plant communities. The Botanical Revi 59(3):155-210

13. Gorai M, Vadel AM, Neffati M (2006) Seed germination characteristics of Phragmites communis: Effects of temperature and salinity. Belg J Bot 139:78-86

14. Grace JB, Wetzel RG (1982) Niche differentiation between two rhizomatous plant species: T. latifolia and T. angustifolia. Canad J Bot 60(1):46-57

15. Haslam SM (1972) Biological flora of the British Isles. P. communis. J Ecol 60:585-610

16. Hotchkiss N, Dozier HL (1949) Taxonomy and distribution of North American Cat-Tails. The Amer Midland Naturalist 4(1):237-254

17. Jesus JM, Calheiros CS, Castro PM, Borges MT (2014) Feasibility of Typha latifolia for high salinity effluent treatment in constructed wetlands for integration in resource management systems. Int $\mathrm{J}$ Phytorem 16(4)

18. Jian YX, Wang JB, He GQ, Chen JK (2001) Effects of water depth gradients, matrices, light and removal of plantlets on germination of turions of Potamogeton crispus L. Acta Hydrobiology Sin 25(3):224-229 
19. Keddy PA, Constabel P (1986) Germination of ten shoreline plants in relation to seed size, soil particle size \& water level: An experimental study. J Ecol 74:133-141

20. Khalid I, Begum I (2020) Hydro politics in Pakistan: perceptions and misperceptions. South Asian Studies 28:1

21. Kim DH, Kim HT, Kim JG (2013) Effects of water depth and soil type on the survival \& growth of Persicaria thunbergii during early growth stages. Ecol Engg 61:90-93

22. Kobe RK, lyer M, Walters MB (2010) Optimal partitioning theory revisited: Non-structural carbohydrates dominate root mass responses to N. Ecol 91:166-179

23. Koropchak S, Vitt D (2013) Survivorship and growth of T. latifolia across a NaCl gradient: a greenhouse study. Int J Mining Reclam Envir 27(2):143-150

24. LiZ, Zhang X, Wan A, Wang H, Xie J (2018) Effects of water depth and substrate type on rhizome bud sprouting and growth in Zizania latifolia. Wetlands Ecol Manag 26(3):277-284

25. Maguire D, Sforza R, Smith SM (2011) Impact of herbivory on performance of Vincetoxicum spp., invasive weeds in North America. Biol Invas 13(5):1229-1240

26. Mauchamp A, Mesleard F (2001) Salt tolerance in Phragmites australis populations from coastal Mediterranean marshes. Aquatic Bot 70:39-52

27. Nagajyoti PC, Dinakar N, Suresh S, Udaykiran Y, Suresh C, Dhamodharam T (2009) Effect of industrial effluent on morphological parameters and chlorophyll content of green gram. J Envir Biol 30(3):385-388

28. Ponnamperuma FN (1972) The chemistry of submerged soils. Advan Agron 24:29-95

29. Romero MI, Onaindia M (1995) Fullgrown aquatic macrophytes as indicators of river water quality in the northwest Iberian Peninsula. In Annales botanici fennici 91-99

30. Rook AJ, Dumont B. Isselstein J, Osoro K, WallisDeVries MF, Parente G, Mills J (2004) Matching type of livestock to desired biodiversity outcomes in pastures- A review. Biol Conser 119(2):137-150

31. Schmidt JP, Drake JM (2011) Why are some plant genera more invasive than others? Plant Sci One 6(4):18654

32. Sharma P, Asaeda T, Fujino T (2008) Effect of water depth on the rhizome dynamics of $T$. angustifolia. Wetlands Ecol Manag 16:43-49

33. Sojda RS, Solberg KL (1993) Management and control of cattails. U.S. Fish and Wildlife Leaflet 13.4.13. 8 p. Washington, D.C

34. Steel RGD, Torrie JH (1980) Analysis of covariance. Principles and procedures of statistics: A Biometrical Approach 401-437

35. Vretare V, Stefan EB, John W, Strand A, Granéli W (2001) Phenotypic plasticity in P. australis as a functional response to water depth. Aquatic Bot 69:127-145

36. VretareV, Weisner SEB (2000) Influence of pressurized ventilation on performance of an emergent macrophytes ( $P$. australis). J Ecol 88:978-987 
37. Vymazal J (2013) Emergent plants used in free water surface constructed wetlands: a review. Ecol Engg 61:582-592

38. Waters I, Shay JM (1991) A field study of the effects of water depth, order of emergence and flowering on the growth of T. glauca shoots using the Richards model. Aquatic Bot 39:231-242

39. Weisner SEB, Strand JA (1996) Rhizome architecture in $P$. australis in relation to water depth: implications for within-plant oxygen transport distances. Folia Geobot Phytotaxon 31:91-97

40. White SD, Ganf GG (1998) The influence of convective flow on rhizome length in T. domingensis over a water depth gradient. Aquatic Bot 62(1):57-70

41. Wood I, Zedler JB (2002) Can nutrients alone shift a sedge meadow towards dominance by the invasive Typha ×. Glauca? Wetlands 22:509-521

42. Zhang XK, Liu XQ, Wang HZ (2015) Effects of water level fluctuations on lakeshore vegetation of three subtropical flood plain lakes, China. Hydrobiologia 747:43-52

43. Zhang XK, Liu XQ, Ding QZ (2013) Morphological responses to water level fluctuations of two submerged macrophytes, Myriophyllum spicatum and Hydrilla verticillata. J Plant Ecol 6:64-70 